\title{
UJI TERATOGENISITAS INFUSA DAUN SELEDRI PADA TIKUS BETINA GALUR WISTAR
}

\author{
Seny Samrotul F., Muharram Priatna, \& Yedy Purwandi S. \\ Dosen STIKes BTH Tasikmalaya Prodi S-1 Farmasi \\ Email: yedipur@gmail.com
}

\begin{abstract}
Abstrak
Seledri merupakan tanaman obat yang secara luas digunakan oleh masyarakat untuk penanganan penyakit hipertensi. Akan tetapi sampai saat ini efek teratogenisitas dari tanaman ini masih belum diketahui., tujuan penelitian ini untuk mengetahui efek teratogenisitas infusa daun seledri. Hewan uji dibagi dalam lima kelompok yaitu kontrol negatif (aquades), kontrol positif (kaptopril 0,45mg/200g BB Tikus), uji 1 (infusa daun seledri 0,09g/200g BB tikus), uji 2 (infusa daun seledri $0,18 \mathrm{~g} / 200 \mathrm{~g}$ BB tikus) dan uji 3 (infusa daun seledri $0,36 \mathrm{~g} / 200 \mathrm{~g}$ BB tikus). Hasil penelitian menunjukkan bahwa infusa daun seledri (Apium graveolens L.) dosis 1, 2 dan 3 tidak menimbulkan efek teratogenik atau malformasi pada janin, tetapi dosis 1 dan 3 mengakibatkan peningkatan kematian pada janin secara signifikan $(p<0,05)$. Selain itu, dosis 3 dapat menurunkan jumlah total janin dan berat badan janin secara signifikan $(p<0,05)$ dengan kemungkinan melalui mekanisme yang sama dengan kaptopril. Berdasarkan hal tersebut, infusa daun seledri tidak direkomendasikan sebagai antihipertensi pada wanita hamil.
\end{abstract}

Kata Kunci: Infusa Seledri, Hipertensi, Teratogenik,

\begin{abstract}
Celery is a medicinal plant that widely used to the treatment of hypertension. However, teratogenic effects of this plant are still unknown. The objective of the study is to determine the teratogenic effects of celery (Apium graveolens L.) water extract. The animals divided into five groups, negative control (aquadest), positive control (captopril 0,45mg/200g BW of rats), test 1 (celery water extract 0,09g/200g BW of rats), test 2 (celery water extract $0,18 \mathrm{~g} / 200 \mathrm{~g} \mathrm{BW}$ of rats) and test 3 (celery water extract $0,36 \mathrm{~g} / 200 \mathrm{~g} \mathrm{BW}$ of rats). The result of the study showed that the test doses of 1,2 and 3 of the celery water extract (Apium graveolens L.) did not cause teratogenic effects or malformations in the fetus, but the dose of 1 and 3 showed an increase of mortality of the fetus $(p<0,05)$. In Addition, the test dose of 3 could also reduce the total number and the weight of the fetus that probably through the same mechanisms as captopril. Therefore, celery water extract is not recommended as an antihypertension in pregnant women.
\end{abstract}

Keywords: Celery, Hypertension, Teratogenic

\section{PENDAHULUAN}

Penggunaan obat selama kehamilan merupakan fenomena yang umum salah satunya penggunaan obat antihipertensi yang dapat mencapai angka $10 \%$ pada keadaan tersebut (Carson dan Gibson, 2017). Spesifikasi penggunaan obat untuk wanita hamil di Eropa harus sesuai persyaratan yang ditetapkan yaitu harus sesuai fakta tentang pengalaman dan kesimpulan manusia dari studi toksisitas praklinis yang relevan untuk penilaian risiko yang terkait dengan paparan selama kehamilan, rekomendasi penggunaan obat berbeda disesuaikan dengan masa kehamilan, dan rekomendasi penatalaksanaan pada situasi terjadinya eksposur yang tidak disengaja (Schaefer dkk, 2007).

Food and Drug Administration Amerika menerapkan kategori kehamilan A,B,C,D dan X, meskipun pada tahun 2015 kategori tersebut mengalami pergantian (Renulal, 2015). Sampai saat ini belum ada spesifikasi penggunaan obat herbal untuk wanita hamil serta masih sedikit studi penggunaan obat herbal untuk wanita hamil meskipun banyak tanaman obat yang 
terbukti empiris sebagai antihipertensi (Sukandar dkk, 2015; sukandar, 2016).

Tanaman seledri telah diketahui dan digunakan secara luas untuk pengobatan hipertensi (Jorge dkk, 2013) dan tidak menutup kemungkinan digunakan pada wanita yang sedang merencanakan kehamilan atau wanita yang sedang hamil yang menderita hipertensi. Akan tetapi sampai saat ini tidak ada penelitian mengenai uji teratogenisitas pada tanaman ini.

Uji teratogenik merupakan uji yang dirancang untuk mengevaluasi efek khusus suatu senyawa pada janin selama masa organogenesis yang merupakan periode kritis selama masa kehamilan dan adanya pengaruh dari luar dapat menimbulkan efek teratogenik. (Subarnas, 1999). Uji teratogenik merupakan uji yang harus dikerjakan bila pemakaian klinis obat diberikan pada masa-masa organogenesis dan kehamilan. Uji ini penting dilakukan mengingat kemungkinan konsumen pemakainya adalah wanita hamil (Syamsudin, 2006; Sukandar, 2011; Christianty, 2012).

\section{METODOLOGI PENELITIAN}

Sonde oral (Europlex), pipet tetes, gelas ukur, gelas kimia (Pyrex), kertas saring, timbangan tikus, kapas, alat bedah, mikroskop, neraca analik (Shimadzu tipe $A Y$ 220), oven, rak tabung, tabung reaksi (Pyrex), sarung tangan, kain flanel, pinset, objek glas, jarum pentul, meja fiksasi, tisu, alat infusa.

Daun seledri, aquadest, amonia, kloroform, asam klorida $2 \mathrm{~N}$, pereaksi mayer, pereaksi buchard, dragendorf, serbuk Mg, amil alkohol, Asam klorida encer, $\mathrm{FeCl}_{3}$, larutan gelatin $1 \%, \mathrm{NaOH}$, eter, pereaksi lieberman burchard, pereaksi anisaldehidasam sulfat atau pereaksi vanillin-asam sulfat, CMC $1 \%$.

Hewan uji yang digunakan dalam penelitian ini adalah tikus putih galur wistar yang berumur sekitar 2-3 bulan, dengan berat badan $200-250 \mathrm{~g}$, ditempatkan pada ruangan dengan suhu $25-30^{\circ} \mathrm{C}$, dan berada dalam kelembaban berkisar 55-80\%, dengan pencahayaan (12 jam terang dan 12 jam gelap). Hewan yang digunakan dalam penelitian ini adalah tikus yang telah dipastikan identitasnya dan dinyatakan sehat, yaitu tikus yang selama proses pemeliharaan tersebut bobot badannya tetap atau tidak berubah tidak lebih dari $10 \%$ dan secara visual keadaannya normal yang artinya tidak kelihatan sakit dan tidak ada cacat bawaan, selain itu diberikan makanan dan minuman secara ad libitum. Sebelum dilakukan pengujian hewan diaklimatisasi selama 5 hari. Perlakuan terhadap hewan uji sesuai dengan Guideline for the care and use of laboratory animal.

Daun seledri yang masih segar diolah menjadi simplisia kering yang dapat digunakan untuk proses infusa. Pembuatan simplisia dilakukan dengan cara daun seledri disortir dengan metode sortasi basah menggunakan air bersih yang mengalir sehingga kotoran dan debu yang menempel pada daun seledri bersih, kemudian dirajang. Setelah itu daun seledri dikeringkan dalam oven pada suhu $40-50^{\circ} \mathrm{C}$, kemudian dihaluskan menggunakan belender.

Simplisia daun seledri di timbang sebanyak 10gram, kemudian dimasukan kedalam panci dan tambahkan air sebanyak $100 \mathrm{ml}$, selanjutnya dipanaskan diatas penangas air pada suhu $90^{\circ} \mathrm{C}$ selama 15 menit sambil diaduk sari selagi panas melalui kain flanel, tambahkan air panas secukupnya melalui ampas hingga volume infusa $100 \mathrm{ml}$.

Pada penelitian ini dilakukan skrining fitokimia pada simplisia dan infusa daun seledri meliputi pemeriksaan senyawa alkaloid, flavonoid, saponin, steroid dan triterpenoid, tanin dan polifenol, monoterpenoid dan seskuiterpenoid, kuinon (Fransworth, 1996).

\section{Prosedur Penelitian Pemeriksaan Daur Estrus}

Hewan uji sebelum dikawinkan, dilakukan pemeriksaan daur estrus untuk mengetahui keteraturan daur estrus 
sehingga dapat diketahui kapan tikus betina siap untuk dikawinkan. Pemeriksaan daur estrus dilakukan dengan metode usap vagina. Cairan apus vagina yang diperoleh diteteskan pada gelas obyek dan diamati tipe sel-sel epitel apus vagina di bawah mikroskop. Berdasarkan temuan tipe sel tersebut, selanjutnya ditentukan fase daur estrus yang sedang dialami oleh hewan uji. Setelah 4 hari dilakukan pemeriksaan ulang untuk memastikan keteraturan daur estrus. Hewan uji yang menunjukkan daur estrus teratur, dipersiapkan untuk dikawinkan, untuk pengujian teratogenisitas.

\section{Perkawinan dan Penetapan Masa Bunting}

Hewan uji yang memiliki daur estrus teratur, selanjutnya dikawinkan dengan pejantan dengan cara dimasukkan dalam satu kandang (jam 5-6 sore merupakan waktu yang paling disenangi). Pagi hari berikutnya, tikus betina dipisahkan dari pejantan, dan diperiksa apus vaginanya secara mikroskopis. Adanya sperma menandakan telah tejadi perkawinan dan ditetapkan sebagai hari ke nol.

\section{Pemberian Dosis Sediaan Uji}

Kelompok kontrol (+) diberi kaptopril, kelompok kontrol (-) diberi Aquadest, kelompok uji I diberikan infusa daun seledri dengan dosis $0,09 \mathrm{~g} / 200 \mathrm{~g}$ BB Tikus, kelompok uji II diberikan dosis $0,18 \mathrm{~g} / 200 \mathrm{~g}$ BB Tikus, dan kelompok uji III diberikan dosis $0,36 \mathrm{~g} / 200 \mathrm{~g}$ BB Tikus. Sediaan uji diberikan lewat jalur oral menggunakan sonde oral. Hewan uji terlebih dahulu ditimbang untuk menentukan volume sediaan uji yang akan diberikan sesuai dengan peringkat dosisnya. Pemberian sediaan uji dilakukan selama masa organogenesis, yaitu mulai hari ke-5 masa bunting sampai hari ke-19 kebuntingan dengan interval sehari satu kali.

\section{Pemeriksaan dan Pengamatan}

Masa pengamatan dimulai sejak diakhirinya masa bunting hewan uji, yakni 12-14 jam sebelum waktu kelahiran normal (hari ke-19) melalui bedah caesar di dalam fume hood. Hewan uji ditimbang dan dianestesi dengan dietil eter, kemudian induk dibedah sampai terlihat uterus yang berisi janin, dan korpora lutea dikeluarkan, kemudian organ tersebut dikeluarkan. Dinding uterus disayat secara longitudinal untuk mengeluarkan janin yang ada di dalamnya, lalu janin dipisahkan dari plasenta. Kemudian dilakukan pengamatan jumlah total janin, janin hidup, janin mati, panjang janin, berat janin, berat tubuh induk, morfologi janin, dan korpus luteum.

\section{HASIL DAN PEMBAHASAN}

Tabel 1. Hasil Skrining Fitokimia Simplisia Daun Seledri

\begin{tabular}{lcc}
\hline \multicolumn{1}{c}{$\begin{array}{l}\text { Metabolit } \\
\text { Sekunder }\end{array}$} & \multicolumn{2}{c}{ Hasil } \\
\cline { 2 - 3 } & Simplisia & Infusa \\
\hline Alkaloid & - & - \\
\hline Flavonoid & + & + \\
\hline Kuinon & - & - \\
\hline $\begin{array}{l}\text { Monoterpenoid dan } \\
\text { seskuiterpenoid }\end{array}$ & - & - \\
\hline Saponin & & + \\
\hline Steroid dan & + & - \\
Triterpenoid & - & + \\
\hline Polifenol & & + \\
\hline
\end{tabular}

Berdasarkan hasil skrining fitokimia terhadap simplisia dan infusa daun seledri menunjukkan positif senyawa flavonoid, saponin dan polifenol. Flavonoid yang terkandung di daun seledri dalam hal ini yaitu apigenin telah terbukti dapat menurunkan tekanan darah dengan beberapa mekanisme kerja seperti menghambat enzim angiotensin converting enzyme, menghambat kanal kalsium dan menghambat reseptor beta-1 di jantung (Ko dkk, 1991; Haixia dkk, 2009; Sukandar, 2015; Sukandar, 2016).

Gambar 2. Pendarahan pada janin.

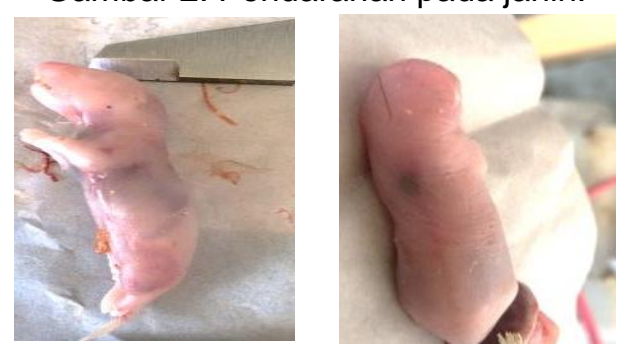


Gambar 1. Siklus estrus (I) fase proestrus (II) fase estrus (III) fase metestrus (IV) fase diestrus.

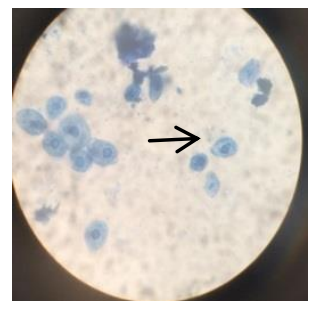

I. Apusan vagina fase proestrus ( $\rightarrow$ sel berinti)

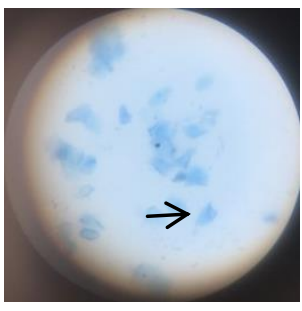

II. Apusan vagina fase estrus. ( $\rightarrow$ sel tanduk )

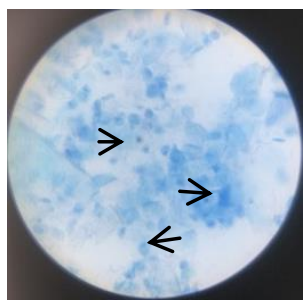

III. Apusan vagina fase metestrus

$\rightarrow$ sel leukosit sel bertanduk sel berinti

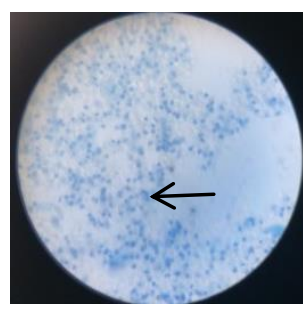

IV. Apusan vagina fase diestrus

$(\rightarrow$ banyak leukosit )

Tabel 2. Jumlah total janin

\begin{tabular}{lccc}
\hline \multirow{2}{*}{ Kelompok } & \multicolumn{3}{c}{ Jumlah Janin } \\
\cline { 2 - 4 } & Hidup & Mati & Total \\
\hline Negatif (Aquades) & $10,20 \pm 2,16$ & 0 & $10,20 \pm 2,16$ \\
\hline Positif (Kaptopril) & $3,00 \pm 2,00^{*}$ & $4,00 \pm 0^{*}$ & $7,00 \pm 2,00^{*}$ \\
\hline D I (Infusa seledri 0,09g/200g) & $8,00 \pm 1,00$ & $2,33 \pm 0,57^{*}$ & $10,33 \pm 0,57$ \\
\hline D II (Infusa seledri $0,18 \mathrm{~g} / 200 \mathrm{~g})$ & $8,20 \pm 2,58$ & $1,20 \pm 1,64$ & $9,40 \pm 1,51$ \\
\hline D III (Infusa seledri $0,36 \mathrm{~g} / 200 \mathrm{~g})$ & $5,33 \pm 2,51^{*}$ & $2,00 \pm 2,00^{*}$ & $7,33 \pm 0,57^{*}$ \\
\hline
\end{tabular}

*Menyatakan terdapat perbedaan yang signifikan $(p<0,05)$ terhadap kelompok negatif

Berdasarkan hasil penelitian yang telah dilakukan, mengenai jumlah janin hidup menunjukkan bahwa kelompok positif dan dosis 3 memberikan perbedaan yang signifikan $(p<0,05)$ dalam jumlah janin hidup dibandingkan kelompok negatif. Jumlah janin hidup pada kelompok positif terjadi penurunan jumlah janin sebesar $70,5 \%$ dan dosis 3 terjadi penurunan sebesar $47 \%$ dibandingkan terhadap kelompok negatif. Kematian tersebut kemungkinan akibat adanya pendarahan atau hipoksia yang ditandai warna kebiruan pada kulit janin seperti yang ditunjukkan pada gambar 2 dibawah.

Hipoksia atau pendarahan yang terjadi mungkin diakibatkan seperti mekanisme yang sama seperti yang diakibatkan oleh kaptopril yaitu melalui penurunan aliran darah ke plasenta yang mengakibatkan kekurangan oksigen dan nutrisi (maternal hypotension) (Buttar, 1987). Selain itu, penurunan tekanan darah dan penurunan konsentrasi angiotensin II memicu mekanisme reaksi kompensasi (untuk mempertahankan tubuh) yang mengakibatkan ginjal mengeluarkan renin- angiotensin sehingga tekanan darah janin meningkat dan dapat mengakibatkan pendarahan (Soares,1995).

Tabel 3. Panjang dan berat Janin

\begin{tabular}{ccc}
\hline Kelompok & $\begin{array}{c}\text { Panjang } \\
\text { Janin }\end{array}$ & $\begin{array}{c}\text { Berat } \\
\text { Janin }\end{array}$ \\
\hline Negatif (Aquades) & $5,19 \pm 0,13$ & $5,01 \pm 0,27$ \\
\hline Positif (Kaptopril) & $5,20 \pm 0,08$ & $5,16 \pm 0,40$ \\
\hline Dosis I & $5,23 \pm 0,14$ & $5,11 \pm 0,22$ \\
\hline Dosis II & $4,22 \pm 0,71^{\star}$ & $3,14 \pm 0,47^{*}$ \\
\hline Dosis III & $5,26 \pm 0,20$ & $4,75 \pm 0,27^{*}$ \\
\hline
\end{tabular}

${ }^{*}$ Menyatakan terdapat perbedaan yang signifikan $(p<0,05)$ terhadap kelompok negatif

Hasil penelitian mengenai panjang janin menunjukan bahwa dosis 2 memberikan hasil yang signifikan $(p<0,05)$ terhadap penurunan panjang janin dibandingkan kelompok negatif. Sedangkan mengenai berat janin dosis 2 dan 3 memberikan hasil yang signifikan $(p<0,05)$ terhadap penurunan berat janin dibandingkan kelompok negatif. Hal ini menunjukan bahwa infusa seledri mempengaruhi panjang dan berat janin. Panjang dan berat janin normal rata-rata 5$5,5 \mathrm{~cm}$ dan $5-6 \mathrm{~cm}$ secara berturut-turut 
(Kauffman 1992; Malole, 1999). Wilson (1973) menyatakan bahwa penurunan berat dan panjang badan janin merupakan parameter yang cukup sensitif untuk mengetahui pengaruh senyawa asing terhadap pertumbuhan janin. Penurunan panjang janin dan penurunan berat janin kemungkinan berhubungan erat dengan efek penurunan tekanan darah yang mengakibatkan kekurangan nutrisi dan oksigen (Soares,1995).

Tabel 4. Berat induk

\begin{tabular}{lc}
\hline \multicolumn{1}{c}{ Kelompok } & $\begin{array}{c}\text { Penambahan } \\
\text { Berat badan induk }\end{array}$ \\
\hline Negatif (Aguadest) & $68,38 \pm 13,39$ \\
\hline Positif (Kaptopril) & $67,82 \pm 0,26$ \\
\hline Dosis I & $60,64 \pm 10,80$ \\
\hline Dosis II & $69,38 \pm 16,98$ \\
\hline Dosis III & $54,31 \pm 3,12$ \\
\hline
\end{tabular}

*Menyatakan tidak terdapat perbedaan yang signifikan $(p<0,05)$ terhadap kelompok negatif

Berat induk sesuai table 4, pada kelompok positif, dosis 1 , dosis 2 dan dosis 3 memberikan hasil yang tidak signifikan $(p>0.05)$ dibandingkan dengan kelompok negatif. hal ini mengindikasikan bahwa infusa daun seledri tidak terlalu mempengaruhi berat induk. Meskipun pada dosis 3 terdapat perbedaan berat badan induk sebesar 20,6\% dibanding kelompok negatif yang mungkin dipengaruhi oleh jumlah total janin dan kematian janin.

Penambahan berat badan induk saat hamil normalnya yaitu sekitar $18-35$ gram dengan kecepatan tubuh mengalami pertambahan berat badan minimal 1 gram/hari (Martijo, 1992). Berat induk tikus berkorelasi dengan perkembangan janin, abortus, bertambahnya volume cairan amnion, plasenta, serta selaput amnion (selaput yang membatasi ruangan tempat terdapatnya embrio) (Arifin, 2007). Apabila berat induk mengalami penurunan pada saat kehamilan kemungkinan terdapat keguguran janin atau hambatan perkembangan pada janin (Silvia, 2011).
Tabel 5. Korpus luteum

\begin{tabular}{|c|c|c|}
\hline Kelompok & $\begin{array}{l}\text { Jumlah } \\
\text { Korpus } \\
\text { luteum }\end{array}$ & Total Janin \\
\hline Negatif (Aquades) & $10,20 \pm 2,16$ & $10,20 \pm 2,16$ \\
\hline Positif (Kaptopril) & $7,00 \pm 2,00$ & $7,00 \pm 2,00$ \\
\hline Dosis I & $7,33 \pm 5,50$ & $7,33 \pm 5,50$ \\
\hline Dosis II & $9,40 \pm 1,51$ & $9,40 \pm 1,51$ \\
\hline Dosis III & $7,33 \pm 0,57$ & $7,33 \pm 0,57$ \\
\hline
\end{tabular}

Berdasarkan hasil penelitian pada kelompok positif sesuai table 5 , dosis 1 , dosis 2 dan dosis 3 tidak ada perbedaan antara jumlah korpus luteum dengan jumlah janin. Hal ini mengindikasikan bahwa tidak ada keguguran janin dalam rahim. Hal ini didukung dengan hasil berat induk yang menyatakan tidak ada perbedaan antara positif dan infusa uji dosis 1 , dosis 2 , dan dosis 3.

Tabel 6. Morfologi janin

\begin{tabular}{lcc}
\hline \multirow{2}{*}{ Kelompok } & \multicolumn{2}{c}{ Malformasi } \\
\cline { 2 - 3 } & Ada & Tidak \\
\hline Negatif (Aquadest) & - & $\sqrt{ }$ \\
\hline Positif (Kaptopril) & - & $\sqrt{ }$ \\
\hline Dosis I & - & $\sqrt{ }$ \\
\hline Dosis II & - & $\sqrt{ }$ \\
\hline Dosis III & - & $\sqrt{ }$ \\
\hline
\end{tabular}

Berdasarkan pengamatan terhadap morfologi janin terdapat pada table 6 , tidak ditemukan malformasi pada janin baik kelompok positif, dosis 1 , dosis 2 , dan dosis 3. Hai ini mengindikasikan bahwa infusa daun seledri tidak memberikan efek teratogenik.

Berdasarkan seluruh rangkaian pengujian teratogenisitas mengindikasikan bahwa infusa daun seledri dengan dosis $0,09 \mathrm{~g} / 200 \mathrm{~g}$ BB tikus, 0,18/200g BB dan $0,36 \mathrm{~g} / 200 \mathrm{~g}$ BB Tikus tidak memberikan efek teratogenisitas. akan tetapi infusa daun seledri terutama dosis $3(0,36 \mathrm{~g} / 200 \mathrm{~g}$ BB Tikus) mengakibatkan peningkatan resiko kematian janin, penurunan jumlah total janin, mempengaruhi panjang janin dan berat janin. 


\section{KESIMPULAN}

Berdasarkan penelitian yang telah dilakukan, infusa daun seledri tidak memberikan efek teratogenik atau malformasi pada morfologi janin, tetapi infusa daun seledri dapat mengakibatkan peningkatan resiko kematian pada janin, penurunan jumlah total janin, menurunkan panjang dan berat badan janin, terutama pada pada dosis $3(0,36 \mathrm{~g} / 200 \mathrm{~g}$ BB Tikus). Oleh karena itu, seledri tidak direkomendasikan sebagai antihipertensi saat kehamilan dan diperlukan penelitian lanjutan mengenai mekanisme kerja yang terlibat serta metabolit sekunder yang bertangggung jawab dalam abnormalitas janin.

\section{DAFTAR PUSTAKA}

Arifin, Helmi, dan Almahdy, (2007). Pengaruh Vitamin C terhadap Fetus pada Mencit Diabetes. Farmasi. FMIPA Universitas Andalas, Jurnal Sains dan Teknologi Farmasi. 12(1) 32-40.

Carson M.P. dan Gibson P.S, (2017). Hypertension and Pregnancy. [Diakses pada 17 januari 2017]. Tersedia di https://emedicine.medscape.com

Christianty F.M. dan Winarti L., (2012). Uji Teratogenik Campuran Serbuk Biji Jinten Hitam (Nigella Sativa L.), Biji Kelabet (Trigonella Foenum-graecum L.), dan Gingseng (Panax gingseng C. A. Mey) Pada Tikus Putih Galur Wistar. 9 (3): 155-161.

Fransworth, N.R., (1966). Biological and Photocemical Screening Of Plant, Journal Of Pharmacetical Scinence. Vol 55. 245-275.

Kauffman M.H., (1992). The atlas of mouse development. Academic Press. New York.

Malole, MBM, Pramono S.U., (1999). Penggunaan Hewan-Hewan Percobaan di Laboratorium. Bogor: Pusat Antar Universitas Bioteknologi IPB.

Martijo, (1992). Kesehatan dan Kemampuan Adaptasi Hewan, Universitas Gadjah Mada, Yogyakarta.
Renulal, (2015). Drugs in Prenancy and Lactation "Improved Benefit-Risk Information. Diakses 18 januari 2018. Tersedia di http://www.fda.gov/cdersmallbusinessc hronicles.

Silvia G.A., (2011). Pengaruh Pemberian Suspensi Akar Manis Terhadap Perkembangan Janin pada Mencit Bunting.

Soares D.M.R \& M.A. Cerqueira L., (1995). Effects of captopril on the human foetal placental circulation: an interaction with bradykinin and angiotensin $\mathrm{I}$. Departamento de Farmacologia e Psicobiologia, IB-HUPE, Centro Biomedico, Universidade do Estado do Rio de Janeiro, Rio de Janeiro, Brasil. 497-501.

Subarnas A, Sumiwi S.A, Fatati, (1999). Uji Teratogenik Ekstrak Etanol Kulit Batang Sintok (Cinnamomum sintoc BL.) Pada Tikus Galur Wistar.

Sukandar E.Y., dkk., (2011). Iso Farmakoterapi 2. Jakarta: Ikatan Apoteker Indonesia.

Sukandar EY, Ridwan A, dan Sukmawan, (2015). Vasodilation Effect of Ethanolic Extract of Anredera cordifolia, Sonchus arvensis $L$ and Ursolic Acid on Isolated Rabbit Aortic and Frog Heart. Int $\mathrm{J}$ Pharm Pharm Sci, Vol 8, Issue 2, 145149.

(2016). Vasodilation Effect of Oleanolic Acid and Apigenin as a Metabolite compound of Anredera cordifolia (Ten) $V$ Steenis on isolated rabbit aortic and frog heart. Int. J. Res Ayurveda Pharm, 7 (5); 82-84.

Syamsudin, Rizkiyan Y, Darmono. 2006. Efek Teratogenik Ekstrak Metanol Biji Petai Cina (Leucaena lucocephala (Lmk) De Wit) Pada Mencit Hamil. Vol 6 (1): 33-36.

Wilson J.G., (1973). Environment and birth defects. Academic Press. New York. 
